\title{
Priming Improves High-temperature Germination of Pansy Seed
}

\author{
William J. Carpenter \\ Department of Environmental Horticulture, Institute of Food and \\ Agricultural Sciences, Gainesville, FL 32611
}

\author{
Joseph F. Boucher \\ Department of Statistics, Institute of Food and Agricultural Sciences, \\ Gainesville, FL 32611
}

Additional index words. Viola $\times$ wittrockiana, thermal inhibition of germination, seed osmoconditioning

\begin{abstract}
The optimum conditions for priming pansy (Viola $\times$ wittrockiana) seeds were in aerated osmotic solutions of polyethylene glycol 8000 (PEG 8000) at - 1.0 MPa for 7 days at 15C. Priming at $-0.8 \mathrm{MPa}$ and $15 \mathrm{C}$ caused $8 \%$ to $26 \%$ of seeds to germinate during 4 to 13 days of priming. Increasing numbers of abnormal seedlings developed when priming was extended beyond 7 days. Final germination percentages were better in laboratory studies at $35 \mathrm{C}$ for primed $(51 \%)$ than nonprimed $(\mathbf{1 0 \%})$ seeds. Removal of the mucilage released by the seed with $240 \mathrm{~g}$ KOH or $170 \mathrm{~g} \mathrm{NaOH} /$ liter for $15 \mathrm{or}$ 30 seconds during priming did not affect total germination percentages, but did improve seed handling. Primed seed had higher, faster, and more uniform germination than nonprimed seeds after sowing in growing medium in plant growth chambers or greenhouses.
\end{abstract}

Pansy is an annual or short-lived perennial widely grown as a bedding plant and occasionally produced for cut flowers. Pansies are cold-tolerant (Post, 1949) and popular for landscaping in regions with cool spring and summer nights, such as northern Europe and the northern regions of the United States. In warm regions of the Northern Hemisphere, pansies are used for fall and winter landscaping, which requires sowing seeds during the hot months. Imbibed pansy seed placed at $30 \mathrm{C}$ or above enter a high-temper-

Received for publication 31 July 1990. Florida Agriculture Experiment Station Journal Series no. R00478. This research was partially supported by a grant from the Bedding Plants Foundation. The cost of publishing this paper was defrayed in part by the payment of page charges. Under postal regulations, this paper therefore must be hereby marked advertisemerrt solely to indicate this fact. ature-induced thermoinhibition stage that causes low total germination (unpublished data), similar to that in lettuce (Guedes and Cantille, 1980).

During seasons of high temperatures, most commercial producers germinate pansy seeds in 18 to $21 \mathrm{C}$ refrigerated rooms and later transplant the seedlings to production flats in evaporatively cooled greenhouses at reduced light intensities. Some producers directly sow seeds in "plug" trays in refrigerated rooms, with trays of seedlings later moved into production greenhouses.

Seed priming in osmotic solutions of PEG 8000 or $\mathrm{K}_{3} \mathrm{PO}_{4}$, and $\mathrm{KNO}_{3}$ salts as osmotica improved the germination of impatiens (Impatiens wallerana Hook) (Simmonds, 1980), lettuce (Lactuca sativa L.) (Cantliffe, 1981), salvia (Sahia splendens F.) (Carpenter, 1989), and tomato (Lycopersicon esculentum) (Rumpel and Szudyga, 1978) at excessively high temperatures. Priming also shortened emergence time, resulted in more uniform germination, and occasionally increased total germination of some seeds (Heydecker, 1977). No recommendations have been reported for priming pansy seed. The major objectives of this research were to develop procedures for priming pansy seed and to determine if priming enhances germination at sub- and supra-optimal temperatures.

Seed priming. Seeds of 'Majestic Giant Yellow' and 'Majestic Giant Red' pansy were primed in 80-ml test tubes containing aerated PEG 8000 solutions at $-0.8,-1.0$, or -1.2 $\mathrm{MPa}$ for $4,7,10$, or 13 days at $15 \mathrm{C}$. The water potential of the PEG 8000 solutions was measured at $15 \mathrm{C}$ with a Wescor vapor pressure osmometer (Wescor Co., Logan, Utah). Following priming, seeds were washed

Table 1. Effect of germination temperature on criteria of germination' of pansy seed nonprimed or primed 7 days with - 1.0 MPa PEG at $15 \mathrm{C}$.

\begin{tabular}{lcccc}
\hline \hline \multirow{2}{*}{$\begin{array}{l}\text { Seed } \\
\text { treatment }\end{array}$} & $\begin{array}{c}\text { Temp } \\
\left({ }^{\circ} \mathrm{C}\right)\end{array}$ & $\begin{array}{c}\mathrm{G} \\
(\%)\end{array}$ & $\begin{array}{c}\mathrm{T}_{50} \\
\text { (days) }\end{array}$ & $\begin{array}{c}\mathrm{T}_{90}-\mathrm{T} \\
\text { (days) }\end{array}$ \\
\hline Nonprimed & 10 & 75 & 11 & 15 \\
& 15 & 85 & 5 & 6 \\
& 20 & 90 & 4 & 4 \\
& 25 & 84 & 4 & 4 \\
& 30 & 56 & 4 & 5 \\
& 35 & 10 & 5 & 6 \\
Primed & 10 & 84 & 6 & 8 \\
& 15 & 87 & 4 & 5 \\
& 20 & 91 & 3 & 3 \\
& 25 & 88 & 3 & 3 \\
& 30 & 84 & 3 & 3 \\
& 35 & 51 & 4 & 5
\end{tabular}

\begin{tabular}{llll} 
Significance & & & \\
Temperature (T) & $* *$ & $* *$ & $* *$ \\
Treatment (TR) & $* *$ & $* *$ & $* *$ \\
$\mathrm{~T} \times \mathrm{TR}$ & $* *$ & $* *$ & $* *$ \\
\hline
\end{tabular}

${ }^{2} \mathrm{G}=$ total germination percentage; $\mathrm{T}_{50}=$ days to $50 \%$ germination; $\mathrm{T}_{90}-\mathrm{T}_{10}=$ days elapsed between $10 \%$ and $90 \%$ germination.

** Significant at $\mathrm{P}=0.01$, data are the means of 400 seeds. 


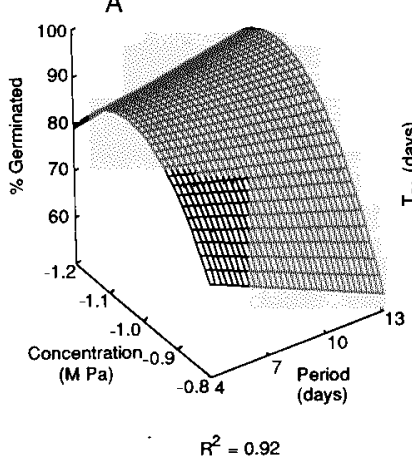

Significance:

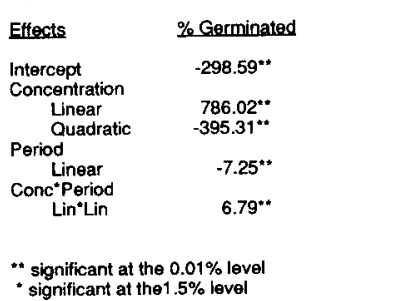

" significant at the $0.01 \%$ level

Fig. 1. The effect of PEG 8000 concentration and priming duration at $15 \mathrm{C}$ on subsequent total germination percent $(\mathbf{A})$, days to $50 \%$ germination $\left(\mathrm{T}_{50}\right)(\mathbf{B})$, and days elapsed between $10 \%$ and $90 \%$ germination $\left(\mathrm{T}_{90}-\mathrm{T}_{10}\right)(\mathbf{C})$ of primed pansy seed germinated at $20 \mathrm{C}$.
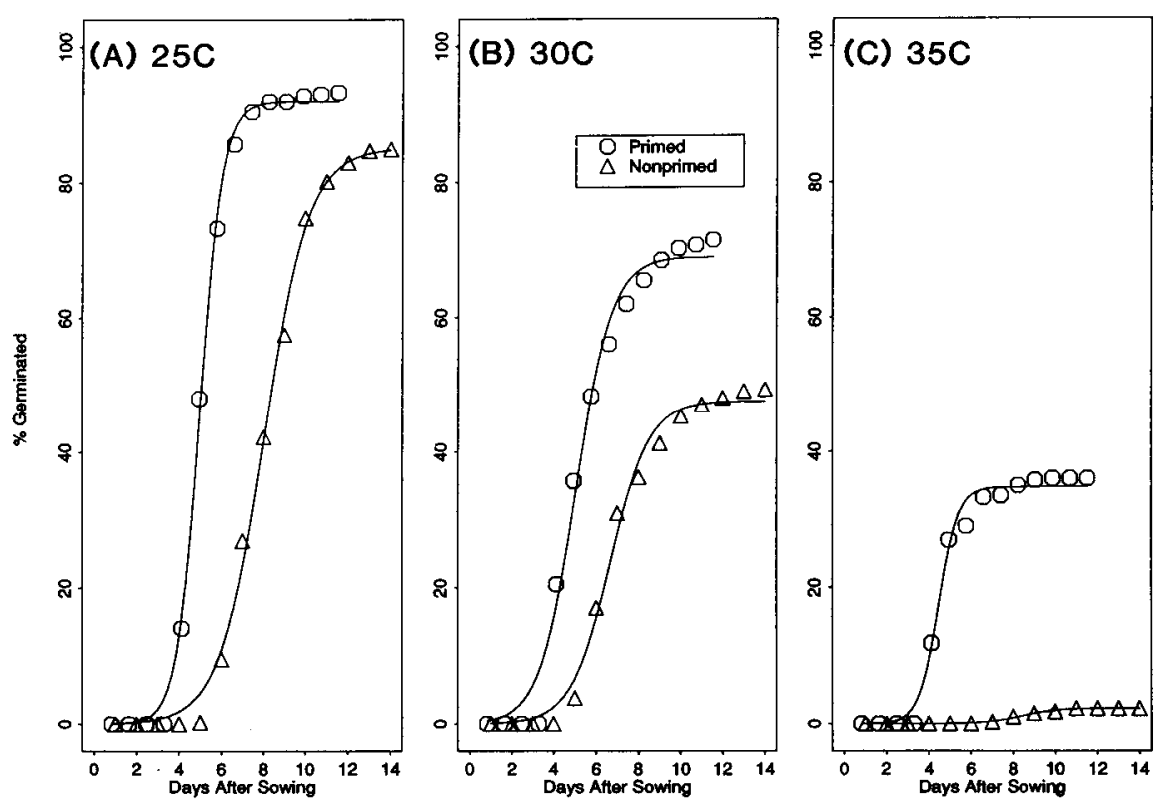

Fig. 2. Cumulative germination of seeds sown in plug trays in plant growth chambers at constant $25 \mathrm{C}$ (A), 30C (B), or 35C (C), comparing seed primed with - 1.0 MPa PEG 8000 at 15C for 7 days with nonprimed seed of 'Majestic Giant Purple' pansy. The estimated values for total germination percent $(\mathrm{G})$, days to $50 \%$ of final germination $\left(\mathrm{T}_{50}\right)$, and rate of increase $(\mathrm{K})$ were obtained with the equation: $\%$ Germination $=\mathrm{G} / 1+\mathrm{e}^{-\mathrm{k}(\mathrm{day}-\mathrm{T} 50)}$, and compared for primed and nonprimed seeds at each temperature using asymptotic $95 \%$ confidence intervals.

$\begin{array}{llrrr}\hat{\mathrm{G}} & \frac{25 \mathrm{C}}{85 \mathrm{a}} & \frac{30 \mathrm{C}}{48 \mathrm{~b}} & \frac{35 \mathrm{C}}{2 \mathrm{~b}} \\ \hat{\mathrm{T}}_{50} & \text { Nonprimed } & 92 \mathrm{a} & 69 \mathrm{a} & 35 \mathrm{a} \\ \hat{\mathrm{K}} & \text { Primed } & 8 \mathrm{a} & 8 \mathrm{a} & 9 \mathrm{a} \\ & \text { Nonprimed } & 6 \mathrm{~b} & 5 \mathrm{~b} & 5 \mathrm{~b} \\ & \text { Primed } & 1.0 \mathrm{~b} & 1.1 \mathrm{~b} & 1.2 \mathrm{~b} \\ & \text { Nonprimed } & 1.6 \mathrm{a} & 1.6 \mathrm{a} & 1.8 \mathrm{a}\end{array}$

with $100 \mathrm{ml}$ of distilled water (DW), surface moisture was removed by $30 \mathrm{~min}$ of vacuum aspiration, and stored for 2 days at SC and
$45 \%$ relative humidity $(\mathrm{RH})$ before germination at 20C. Treatments consisted of four 100-seed replications, each germinated in 9-
Table 2. Total germination percentage of primed and nonprimed pansy seed after removal of the mucilaginous seed cover by chemical soaking treatment.

\begin{tabular}{|c|c|c|c|c|}
\hline \multicolumn{3}{|c|}{ Seed treatment } & \multicolumn{2}{|c|}{$\begin{array}{l}\text { Germination of } \\
\text { 20C }(\%)\end{array}$} \\
\hline Chemical & $\begin{array}{c}\text { Conce } \\
(\%)\end{array}$ & $\begin{array}{l}\text { Soakin } \\
(\min )\end{array}$ & $\begin{array}{l}\text { ng Non- } \\
\text { primed }\end{array}$ & Primed \\
\hline None & --- & --- & 89 & 90 \\
\hline \multirow[t]{2}{*}{$\mathrm{NaOH}$} & 17 & 0.25 & 86 & 88 \\
\hline & 17 & 0.5 & 92 & 90 \\
\hline \multirow[t]{2}{*}{$\mathrm{KOH}$} & 24 & 0.25 & 93 & 87 \\
\hline & 24 & 0.5 & 90 & 85 \\
\hline \multirow[t]{3}{*}{$\mathrm{NaOCl}$} & 1.3 & 3.0 & 91 & 92 \\
\hline & 2.6 & 3.0 & 88 & 86 \\
\hline & 3.9 & 3.0 & 76 & 53 \\
\hline \multicolumn{5}{|c|}{ Significance } \\
\hline \multicolumn{3}{|c|}{ Tukey's HSD $(P=0.05)$} & 7 & 8 \\
\hline
\end{tabular}

$\mathrm{cm}$ petri dishes containing two Whatman No. 1 filter papers moistened with $5 \mathrm{ml}$ of $\mathrm{DW}$; seeds were germinated in the dark. Daily germination counts were made of seeds with visible radicle protrusion through the testa. Total germination percentage $(\mathrm{G})$, mean emergence time [days to $50 \%$ of final germination $\mathrm{T}_{50}$, using the formula of Furutani et al. (1985)], and span of emergence in days between $10 \%$ and $90 \%\left(\mathrm{~T}_{90}-\mathrm{T}_{10}\right)$, obtained by probit analysis (Ingram and Buchanan, 1984), were calculated for this and subsequent studies. The experimental design was a randomized complete block arranged as a $4 \times 3 \times 2$ factorial, with data tested using an analysis of variance (ANOVA) and a multiple regression analysis.

Germination temperature. Laboratory studies compared the seed germination of 'Majestic Giant Yellow' after priming in aerated solutions of - 1.0 MPa PEG 8000 for 7 days at $15 \mathrm{C}$. Seeds were prepared, as described above, before germination in incubators at a constant $10,15,20,25,30$, or $35 \mathrm{C}$. Treatments consisted of four 100-seed replications. Daily counts were made of seeds with emerged radicles. The experimental design was a randomized complete block arranged as a 3 x 6 factorial, with $G, T_{50}$, and $\mathrm{T}_{90}-\mathrm{T}_{10}$ analyzed by ANOVA.

Removal of mucilaginous seed cover. 'Majestic Giant Yellow' pansy seeds were primed in aerated - 1.0 MPa PEG 8000 solutions for 7 days at $15 \mathrm{C}$, then washed with $100 \mathrm{ml}$ of $\mathrm{DW}$, and surface-dried. Treatments containing four 100-seed replications were placed in $240 \mathrm{~g} \mathrm{KOH}$ or $170 \mathrm{~g} \mathrm{NaOH} /$ liter for 15 or $30 \mathrm{sec}$ or in 13,26 , or $39 \mathrm{~g}$ $\mathrm{NaOCl} /$ liter for $3 \mathrm{~min}$ (Robinson, 1983). Seeds were placed in $10-\mathrm{ml}$ glass vials, the solution was added, and the container was sealed and shaken for the alloted period before removing the solvent by filtration through a screen. Seeds were rinsed immediately with DW for 5 rein, air-dried on filter paper overnight, and germinated at $20 \mathrm{C}$ in petri dishes as previously described. The experimental design was a randomized complete block with data analyzed by ANOVA and Tukey's honestly significant difference test at $P=0.05$.

Direct seeding. Seeds were primed in aerated solutions and prepared as described 
Table 3. Effect of constant 25, 30, or 35C temperatures in plant growth chambers and 32C days/24C nights in greenhouse trials on $G, T_{50}$, and $T_{90}-T_{10}$ of pansy seed nonprimed or primed 7 days in PEG 8000 at $-1.0 \mathrm{MPa}$ and $15 \mathrm{C}$.

\begin{tabular}{|c|c|c|c|c|c|}
\hline \multirow[b]{2}{*}{ Trial } & \multirow[b]{2}{*}{$\begin{array}{c}\text { Seed } \\
\text { treatment }\end{array}$} & \multirow[b]{2}{*}{$\begin{array}{l}\text { Temp } \\
\left({ }^{\circ} \mathrm{C}\right)\end{array}$} & \multicolumn{3}{|c|}{ Germination $^{2}$} \\
\hline & & & $\begin{array}{c}G \\
(\%)\end{array}$ & $\begin{array}{c}\mathrm{T}_{50} \\
\text { (days) }\end{array}$ & $\begin{array}{c}\mathrm{T}_{90}-\mathrm{T}_{10} \\
\text { (days) }\end{array}$ \\
\hline \multirow{6}{*}{ Growth chamber } & Nonprimed & 25 & 83 & 8 & 5 \\
\hline & & 30 & 55 & 8 & 5 \\
\hline & & 35 & 3 & $\cdots$ & -- \\
\hline & Primed & 25 & 92 & 6 & 3 \\
\hline & & 30 & 72 & 6 & 4 \\
\hline & & 35 & 36 & 7 & 5 \\
\hline \multirow{2}{*}{ Greenhouse } & Nonprimed & $24 / 32$ & 79 & 6 & 4 \\
\hline & Primed & $24 / 32$ & 91 & 5 & 4 \\
\hline \multicolumn{6}{|l|}{ Significance } \\
\hline Temperature (T) & & & $* *$ & NS & $*$ \\
\hline Treatment (TR) & & & $* *$ & $*$ & $*$ \\
\hline $\mathrm{T} \times \mathrm{TR}$ & & & $* *$ & $*$ & NS \\
\hline
\end{tabular}

${ }_{\text {NS }}^{2}$ See Table 1 for definition of terms.

, $*$, **Nonsignificant or significant at $P=0.05$ or 0.01 , respectively.

above. Treatments containing four 112-seed replications were sown in 392-cell "plug" trays containing moist Vergro Transplant Mix B (Vergro Co., Tampa, Fla.). Seeds were covered with $2 \mathrm{~mm}$ of screened medium and germinated with clear plastic covers over the trays. The inside of the cover and medium were syringed daily with DW to maintain a high RH. Plant growth chambers were held at 25,30 , or $35 \mathrm{C}$, while the daily mean highs and lows in the greenhouse were 32 and $24 \mathrm{C}$. Growth chambers were lighted $12 \mathrm{~h}$ daily with cool-white fluorescent and incandescent lamps providing $213 \mu \mathrm{mol} \cdot \mathrm{s}^{-1} \cdot \mathrm{m}^{-2}$ and 118 $\mu \mathrm{mol} \cdot \mathrm{s}^{-1} \cdot \mathrm{m}^{-2}$ photosynthetic photon flux, respectively, and the maximum greenhouse light intensity was $455 \mu \mathrm{mol} \cdot \mathrm{s}^{-1} \cdot \mathrm{m}^{-2}$. Germination counts were made at the same hour each day in greenhouses and plant growth chambers of those seedlings that emerged through the medium surface. The experimental design was a randomized complete block, with the data for $\mathrm{G}$ of primed and nonprimed seeds at 25,30 , or $35 \mathrm{C}$ plant growth chambers analyzed by nonlinear regression procedures using SAS (SAS Institute, 1985) proc nlin, with estimated values compared using the asymptotic $95 \%$ confidence intervals.

Germination responses were similar for 'Majestic Giant Yellow' and 'Majestic Giant Red' primed at each PEG 8000 concentration; therefore, data for both cultivars were combined in Fig. 1. No differences were found among blocks, so blocks were not included in the regression analysis. Analysis of the response to $\mathrm{G}$ resulted in a regression equation with four terms: a) linear $\mathrm{x}$ linear (PEG 8000 concentration $x$ priming duration) interactive terms, b) a negative linear term for priming duration, c) linear, and d) quadratic terms for PEG 8000 concentration. A significant interaction existed at the -0.8 MPa priming level, where a decreasing trend in $\mathrm{G}$ paralleled an increase in priming duration from 4 to 13 days (Fig. 1A). At the - 1.2 MPa priming concentration, $\mathrm{G}$ increased as the priming duration increased from 4 to 13 days. A trend of increasing $G$ occurred as priming concentrations were in- creased from $-0.8 \mathrm{MPa}$ to a maximum at - 1.1 MPa, then declining to - 1.2 MPa. As a result of the quadratic trend, no differences in $\mathrm{G}$ were found at -1.0 or -1.2 $\mathrm{MPa}$ for 10 and 13 days, but at 4 and 7 days priming, the $\mathrm{G}$ at $-1.0 \mathrm{MPa}$ was higher. Lower $\mathrm{G}$ resulted from $-0.8 \mathrm{MPa}$ than from - 1.0 or $-1.2 \mathrm{MPa}$ concentrations at all durations of priming (Fig. 1A). Reduced G resulted at $-0.8 \mathrm{MPa}$ because of seed radicle emergence during priming. Elongation of the seed radicle during priming in $-0.8 \mathrm{MPa}$ osmoticum resulted in reduced $\mathrm{G}$ after seed drying and storage for 2 days. Germination of $8 \%, 17 \%, 21 \%$, and $26 \%$ of seed occurred during priming for $4,7,10$, and 13 days at $15 \mathrm{C}$, respectively. These germination data were not included for $-0.8 \mathrm{MPa}$ in Fig. 1 .

The analyses for days to $T_{50}$ and $T_{90}-$ $T_{10}$ showed trends similar to those for $G$. The days for both declined as the duration of priming increased (Fig. $1 \mathrm{~B}$ and C), with linear and quadratic responses with changes in PEG 8000 concentrations. The linear and quadratic trend lines for osmotic concentrations in days to $T_{50}$ and $T_{90}-T_{10}$ progressively increased from - 0.8 $\mathrm{MPa}$ to $1.2 \mathrm{MPa}$. The rates of increase were greater from -0.8 $\mathrm{MPa}$ to $-1.0 \mathrm{MPa}$ than from - 1.0 MPa to - 1.2 MPa (Fig. $1 \mathrm{~B}$ and C). The negative linear term for priming duration indicated that the days to $T_{50}$ or $T_{90}-T_{10}$ will decrease as the priming duration increased from 4 to 13 days, regardless of the concentration of the osmotic solution.

The benefits from seed priming were found to vary with germination temperature. At 15 to $25 \mathrm{C}$, the recommended temperature range for pansy germination, $G$ was similar for primed and nonprimed seeds (Table 1). Nonprimed seed germination percentages decreased with temperatures above or below the 15 to $25 \mathrm{C}$ range, but $\mathrm{G}$ decreased less in primed treatments. This pattern resulted in primed seeds having significantly higher $G$ at 10,30 , or $35 \mathrm{C}$ than nonprimed seeds. Seeds primed had 5 times the $\mathrm{G}$ at $35 \mathrm{C}$ of nonprimed seed (10\% vs. $51 \%)$.

Seeds primed had lower $\mathrm{T}_{50}$ and $\mathrm{T}_{90}-$ $\mathrm{T}_{10}$ than nonprimed seeds. Treatment differ- ences were smaller at favorable germination temperatures of 20 to $30 \mathrm{C}$ and increased at 10,15 , or $35 \mathrm{C}$. The germination delay of nonprimed seed at unfavorable temperatures may have resulted from slower reactivation of essential enzymes. Heydecker (1977) and Heydecker and Coolbear (1977) reported that hydration of seeds during priming enhanced the embryos' ability to synthesize protein and RNA, resulting in earlier germination even under unfavorable environments.

Soaking primed and nonprimed 'Majestic Giant Yellow' pansy seed in $170 \mathrm{~g} \mathrm{NaOH}$ or $240 \mathrm{~g} \mathrm{KOH} /$ liter for 15 or $30 \mathrm{sec}$ or 13 to $26 \mathrm{~g} \mathrm{NaOCl} /$ liter for $3 \mathrm{~min}$ removed most of the mucilaginous seed cover. The chemical concentrations and durations of treatments used, except $39 \mathrm{~g} \mathrm{NaOC} 1 /$ fiter for $3 \mathrm{rein}$, had no effect on $G$ (Table 2). Both reduced $G$, and the latter treatment injured the seedlings. No quantitative measurements of remaining seed mucilage were made, but seed handling and storage were improved. The problem of primed or imbibed pansy seeds being tightly bound together by the mucilage after drying was greatly reduced.

Seed primed in aerated PEG 8000 osmoticum at $-1.0 \mathrm{MPa}$ for 7 days at $15 \mathrm{C}$ and prepared and stored 3 days had higher $\mathrm{G}$ than nonprimed seeds when sown directly in plug trays and germinated in plant growth chambers or greenhouses (Table 3). Primed seeds germinated in plant growth chambers at constant 2.5 or $30 \mathrm{C}$ had $9 \%$ or $17 \%$, respectively, higher $\mathrm{G}$ than nonprimed seed (Table 3). Primed seed sown directly and germinated in plant growth chambers required fewer days to $T_{50}$ and $T_{90}$ $-\mathrm{T}_{10}$ than nonprimed seed. Primed seed $\mathrm{T}_{50}$ at 2.5 and $30 \mathrm{C}$ required $35 \%$ and $32 \%$ fewer days, respectively, than nonprimed seeds. The emergence spans $\left(T_{90}-T_{10}\right)$ for primed seed at 25 and $30 \mathrm{C}$ were $34 \%$ and $12 \%$ shorter, respectively, than nonprimed seeds (Table 3 ). No differences were found between the cumulative germination curves for primed and nonprimed seed at $25 \mathrm{C}$ in plant growth chambers, but significantly larger total germination percentages for primed seed were found at 30 and $35 \mathrm{C}$ (Fig. 2). The periods of rapid germination occurring between days 5 and 8 at $25 \mathrm{C}$ became progressively decreased at $30 \mathrm{C}$ and $35 \mathrm{C}$ for primed and nonprimed seeds, but primed seeds continued to have higher G. Primed seed sown directly in growing medium and germinated in greenhouses at temperatures alternating between $32 \mathrm{C}$ days/24C nights had G $12 \%$ higher than nonprimed seed (Table 3 ). The $\mathrm{T}_{50}$ and $\mathrm{T}_{90}-\mathrm{T}_{10}$ for primed seed were $13 \%$ and $23 \%$ shorter, respectively, than for nonprimed seeds.

The results from the laboratory experiments showed that priming seeds for 7 days at $15 \mathrm{C}$ was best using PEG 8000 at $-1.0 \mathrm{MPa}$. A higher incident of abnormal seedlings was found when priming was increased from 7 to 13 days. Only $2 \%$ of the seedlings were abnormal following priming for 7 days at $15 \mathrm{C}$, and $9 \%$ and $16 \%$ after priming for 10 and 13 days, respectively. The major abnormality was a delay in or failure of the leaves to emerge from the seed. Bewley and Black (1986) report a similar condition can result when imbibed seeds 
are maintained for extended periods under anaerobic conditions.

Pansies are cold-tolerant, but $\mathrm{G}$ of nonprimed seed declined at constant $10 \mathrm{C}$, and days to $\mathrm{T}_{50}$ and $\mathrm{T}_{90}-\mathrm{T}_{10}$ at 10 and $15 \mathrm{C}$ were significantly increased. Seed priming at $15 \mathrm{C}$ limited the reduction in $\mathrm{G}$ at suboptimal germination temperatures and significantly reduced the days to $T_{50}$ and $T_{90}-T_{10}$. Although priming reduces the time required for germination, it cannot replace more favorable temperatures. These results are similar to those of O'Sullivan and Bouw (1984), who concluded that low-temperature germination and emergence of pepper (Capsicum annum L.) seed was accelerated by seed priming.

Nonprimed seeds had large reductions in $\mathrm{G}$ at constant 30 and $35 \mathrm{C}$, with few imbibed seeds germinating at 35C. Foard and Haber (1966) reported that imbibed lettuce seeds that failed to germinate at $35 \mathrm{C}$ had high respiration rates and continued cell division. They believed high temperatures prevented the cell elongation needed for radicle protrusion to occur. Heydecker and Coolbear (1977) reported that seeds complete a high-temperature-sensitive phase during priming, thereafter permitting germination at otherwise unfavorable temperatures.

In our studies, although $36 \%$ to $51 \%$ of primed pansy seeds germinated at constant $35 \mathrm{C}$, radicle lengths were reduced and emergent seedlings lacked the vigor necessary for commercial production. Comparing germination in plant growth chambers at constant $35 \mathrm{C}$ with greenhouses at daily 24 to $32 \mathrm{C}$ alternating temperatures showed that those seeds receiving alternating temperatures had significantly higher $\mathrm{G}$ and reduced $\mathrm{T}_{50}$ and $\mathrm{T}_{90}$ $-\mathrm{T}_{10}$. The capacity of primed seed to achieve $91 \% \mathrm{G}$ at alternating 24 to $32 \mathrm{C}$, while maintaining adequate seedling vigor and quality, indicated the potential exists for germination of direct-seeded primed pansy seeds in greenhouses at some supra-optimal temperatures.

\section{Literature Cited}

Bewley, J.D. and M. Black. 1986. Seeds: Physiology of development and germination. Plenum Press, London.

Cantliffe, D.J. 1981. Priming of lettuce seed for early and uniform emergence under conditions of environmental stress. Acta. Hort. 122:2938.

Carpenter, W.J. 1989. Salvia splendens seed pregermination and priming for rapid and uniform plant emergence. J. Amer. Soc. Hort. Sci. 114:247-250.

Foard, D.E. and A.H. Haber. 1966. Mitosis in thermodormant lettuce seeds with reference to histological location, localized expansion, and seed storage. Planta 71:160-170.

Furutani, S. C., B. H. Zandstra, and H.C. Price. 1985. Low temperature germination of celery seeds for fluid drilling. J. Amer. Soc. Hort. Sci. 110:153-156.

Guedes, A.C. and D.J. Cantliffe. 1980. Germination of lettuce seeds at high temperature after seed priming. J. Amer. Soc. Hort. Sci. 105:777781 .

Heydecker, W. 1977. Stress and seed germination: An agronomic view, p. 237-276. In: A.A. Khan (ed.). The physiology and biochemistry of seed dormancy and germination. North Hol- land Publishing Co., Amsterdam.

Heydecker, W. and P. Coolbear. 1977. Seed treatments for improved performance-survey and attempted prognosis. Seed Sci. Technol. 5:353425 .

Ingram, D.L. and D.W. Buchanan. 1984. Lethal high temperatures for roots of three citrus rootstock. J. Amer. Soc. Hort. Sci. 109:189-193.

O'Sullivan, J. and W.J. Bouw. 1984. Pepper seed treatment for low-temperature germination. Can. J. Plant Sci. 64:387-393.

Post, K. 1949. Florist crop production and marketing. Orange-Judd, New York.
Robinson, T. 1983. The organic constituents of higher plants. Cordus Press, North Amherst, Mass.

Rumpel, J. and 1. Szudyga. 1978. The influence of pre-sowing seed treatments on germinations and emergence of tomato 'New Yorker' at low temperatures. Sci. Hort. 9:119-125.

SAS Institute. 1985. SAS user's guide: Statistics. version 5 ed. SAS Institute, Cary, N.C.

Simmonds, J. 1980. Increasing seedling establishment of Impatiens wallerana in response to low temperature or polyethylene glycol seed treatments. Can. J. Plant Sci. 60:561-569. 